\title{
The Irony of Iron - Biogenic Iron Oxides as an Iron Source to the Ocean
}

\author{
David Emerson * \\ Bigelow Laboratory for Ocean Sciences, East Boothbay, ME, USA
}

Primary productivity in at least a third of the sunlit open ocean is thought to be ironlimited. Primary sources of dissolved iron $(\mathrm{dFe})$ to the ocean are hydrothermal venting, flux from the sediments along continental margins, and airborne dust. This article provides a general review of sources of hydrothermal and sedimentary iron to the ocean, and speculates upon the role that iron-cycling microbes play in controlling iron dynamics from these sources. Special attention is paid to iron-oxidizing bacteria (FeOB) that live by oxidizing iron and producing biogenic iron oxides as waste products. The presence and ubiquity of FeOB both at hydrothermal systems and in sediments is only beginning to be appreciated. The biogenic oxides they produce have unique properties

OPEN ACCESS

Edited by: Jason Raymond,

Arizona State University, USA

Reviewed by:

Mustafa Yucel,

Middle East Technical University,

Turkey

James F. Holden

University of Massachusetts Amherst,

USA

*Correspondence:

David Emerson

demerson@bigelow.org

Specialty section:

This article was submitted to

Microbiological Chemistry

and Geomicrobiology,

a section of the journal

Frontiers in Microbiology

Received: 27 October 2015 Accepted: 14 December 2015

Published: 06 January 2016

Citation:

Emerson D (2016) The Irony of Iron -

Biogenic Iron Oxides as an Iron

Source to the Ocean.

Front. Microbiol. 6:1502.

doi: 10.3389/fmicb.2015.01502 that could contribute significantly to the dynamics of $\mathrm{dFe}$ in the ocean. Changes in the physical and chemical characteristics of the ocean due to climate change and ocean acidification will undoubtedly impact the microbial iron cycle. A better understanding of the contemporary role of microbes in the iron cycle will help in predicting how these changes could ultimately influence marine primary productivity.

Keywords: iron-oxidation, iron-oxidizing bacteria, iron cycle, biogenic iron, hydrothermal vents, hydrothermal diffuse flow, sediment transport, marine iron limitation

\section{INTRODUCTION}

An oceanographer on the deck of a research vessel in the center of a mid-ocean gyre adds a milliliter of a dilute solution of iron chloride to a tank of seawater, she has collected and creates an algae bloom. Three thousand meters below the ship, an undersea hydrothermal vent emits iron-rich vent fluids feeding a unique community of lithoautotrophic iron-oxidizing bacteria $(\mathrm{FeOB})$ that grow in a microbial mat a meter or more thick. Yet, due to the chemistry of iron and the physical structure of the ocean, virtually none of this iron reaches the sea surface; such is the irony of iron.

The Earth's core is composed of iron and it is the fourth most abundant element in the crust; yet the primary production of phytoplankton in $30-40 \%$ of the world's oceans is limited by iron. In the presence of oxygen at oceanic $\mathrm{pH}$, reduced, dissolved ferrous iron [Fe(II)] will oxidize spontaneously to ferric $\mathrm{Fe}(\mathrm{III})$ iron, a one electron transfer, and Fe(III) will instantaneously react with water to form an iron oxyhydroxide with a vanishingly small solubility. In the photic zone of the well-oxygenated modern ocean these oxides precipitate to the depths leaving the surface waters anemic. Interestingly, the reason we refer to anemia at all is because nature has taken advantage of iron's facility for interacting with oxygen to make it central to heme that carries oxygen in our blood. Plants, including single celled algae, take advantage of the redox properties of iron to aid multiple steps in the photosynthetic conversion of light energy to chemical energy 
(Raven et al., 1999); therefore, a lack of available iron limits their growth. The reaction center of nitrogenase, the enzyme responsible for nitrogen fixation, also requires iron (Anderson et al., 2013); hence, biological $\mathrm{N}_{2}$-fixation can become ironlimited as well.

The dynamics of the iron cycle in the ocean are thus of great importance. In the coastal ocean, terrestrial inputs from rivers and turbulent mixing of sediment layers provide an adequate source of iron, such that coastal surface waters are rarely iron-limited. In the open ocean, well clear of the continental shelves, Aeolian dust blowing off the continents is the primary source of iron to the surface waters (Moore and Braucher, 2008). This is why the mid-Atlantic, downwind of the Sahara, has some of the highest surface iron concentrations $(\sim 0.76 \mathrm{nM})$ of any ocean (Raiswell and Canfield, 2011). The converse is true throughout the higher latitudes of the southern ocean, where geography and climate limit the input of dust-borne iron (Martin et al., 1990), and surface ocean iron concentrations may be 5-10 times below North Atlantic values. At these concentrations iron can become the limiting nutrient for the growth of phytoplankton. Mineral debris transported via icebergs that calve from the Antarctic continent can partially supplant Aeolian dust as an iron source to the southern ocean (Raiswell and Canfield, 2011). Nonetheless, from a global perspective, these are among the most anemic waters in the world with correspondingly low rates of primary productivity.

Remarkably, specific groups of bacteria and archaea learned long ago to take advantage of the one electron transfer between $\mathrm{Fe}(\mathrm{II})$ and $\mathrm{Fe}(\mathrm{III})$ to capture energy to support their growth (Emerson et al., 2010). The most prolific of these FeOB require $\mathrm{Fe}(\mathrm{II})$ concentrations in the micromolar range, orders of magnitude higher than are in typical seawater. They grow best at low oxygen concentrations where there is less competition with chemical iron oxidation (Emerson et al., 2010). This restricts FeOB to areas of the ocean floor where such conditions prevail around areas of hydrothermal activity, or sediments that promote the iron cycle.

\section{HYDROTHERMAL VENT ASSOCIATED IRON-UTILIZING COMMUNITIES}

In the deep ocean, hydrothermal vents are generally recognized as the most significant source of iron, and are the most wellstudied habitats for FeOB. Vent systems make up only a tiny percentage of the areal extent of the seafloor yet emit remarkable quantities of iron and sulfur minerals with current estimates for iron-release being on the order of $50 \mathrm{Gg} \mathrm{yr}^{-1}$ (Raiswell and Canfield, 2011). A relatively recent discovery is that these ironrich plumes can be transported 1000s of kilometers from their source. This can be due to nano- and micro-particulate iron sulfide minerals derived from high temperature black smokers (Yücel et al., 2011; Gartman et al., 2014), or fine particulates of iron bound to organic matter (Toner et al., 2009; Bennett et al., 2011; Wu et al., 2011). In either case, these nanoparticles contribute to the pool of dissolved iron ( $\mathrm{dFe}$ ) in the ocean.
$\mathrm{dFe}$ is commonly defined as iron that passes through a $0.2 \mu \mathrm{m}$ filter; irregardless of its oxidation state or elemental composition (Raiswell and Canfield, 2011).

These findings controvert the conventional wisdom that ventsourced iron quickly precipitates from the water column, and has led to a re-evaluation of the potential for hydrothermal iron sources to contribute to the overall iron budget of the ocean (Tagliabue et al., 2010; Fitzsimmons et al., 2014). Furthermore, it has also been assumed that the chemocline that creates a strong physical separation of surface and deep waters would minimize input of hydrothermally derived iron to the surface ocean, except in areas of strong upwelling. Modeling evidence from the southern ocean suggests that a relatively small, but still significant fraction of this deeply sourced iron could end up in the photic zone, and act as an 'iron buffer' to dust borne iron deposition (Tagliabue, 2014; Tagliabue et al., 2014). The guiding hypothesis presented by Tagliabue et al. (2014) is that hydrothermal sources are a more constant $\mathrm{dFe}$ source over geological time scales, than dust borne deposition that is strongly influenced by periods of glaciation and deglaciation with concomitant changes in sea level.

Given the importance of hydrothermal vents as a dFe source for the global ocean, it is reasonable to ask how microbes involved in the iron cycle, and $\mathrm{FeOB}$, in particular, may exert influence on this process. These bacteria grow most prolifically at colder $\left(<100^{\circ} \mathrm{C}\right)$ diffuse flow sources, as opposed to the high temperature $\left(\geq 350^{\circ} \mathrm{C}\right)$ black smokers. These diffuse vents are often more highly enriched in $\mathrm{Fe}$ (II) than reduced sulfur species (Emerson and Moyer, 2010). At these sites, microbial mats composed largely of biogenic iron oxides, referred to here as iron mats, can be centimeters or more thick. These iron mats harbor unique microbial communities dominated by the Zetaproteobacteria, a class of Proteobacteria that is found preferentially in high iron habitats in the ocean, and whose cultured members are lithotrophic FeOB (Scott et al., 2015). Members of this group produce diverse, filamentous micrometer-scale biogenic iron oxides, such as helical stalks and hollow, tubular sheaths that are easily recognized by light microscopy (Chan et al., 2010). These structures prevent the cells from becoming entombed in an impermeable iron-oxide shell. In addition, because the microbes are attached, the filaments provide a means for cells to maintain position in optimal fluxes of $\mathrm{Fe}(\mathrm{II})$ and $\mathrm{O}_{2}$ required for growth.

Detailed mineralogical analysis of these biogenic oxides find the predominant mineral is an amorphous ferrihydrite that is uniquely stable, and slow to undergo diagenesis to more crystalline iron oxides (Toner et al., 2008; Toner, 2012). It is not clear whether this stability is due to silicification, organic components produced by the bacteria, or some combination thereof. At present, our understanding of the organic components of biogenic iron oxides is limited to spectroscopic studies that indicate they are most likely biopolymers of acidic polysaccharides (Chan et al., 2010) that can also adsorb and assimilate organic carbon from their surroundings (Bennett et al., 2014). A more detailed biochemical analysis of the composition of stalks, sheaths, or other filamentous structures produced by marine FeOB has yet to be attempted. 
Genomic analysis of Fe-oxidizing Zetaproteobacteria reveals subunits of genes annotated as cellulose synthases are quite common in gene involved in exopolymer production (Emerson, unpublished results). While cellulose polymers have yet to be found in cultured, stalk-forming Zetaproteobacteria, one function of these types of exopolymers could be to aid in buoyancy of the cells. Consistent with this, an analysis of intact microbial iron mats from Loihi Seamount revealed a remarkable level of coordination in the growth of stalk-producing FeOB to produce cohesive cauliflower-like structures that grow away from rock surfaces and toward the water column (Chan et al., submitted). This mechanism of growth is advantageous in keeping the cells at the mat front close to oxygenated seawater, while still being exposed to Fe(II) coming from vent fluid. The important point is that this growth strategy results in relatively buoyant, biogenic iron oxides that have the potential to become entrained in the water column.

The fate of these biologically precipitated iron oxides is poorly understood. When produced in the vicinity of black smokers, it is possible they can become entrained in the higher temperature plumes. One study that looked at particle sedimentation rate from vent plumes that arose from black smokers at $9^{\circ} \mathrm{N}$ on the East Pacific Rise found evidence of Zetaproteobacteria in a trap further 'down-plume', but not in a trap closer to the vents (Sylvan et al., 2012). This is consistent with the relatively buoyant nature of biogenic oxides, and indicates their potential to be transported in the water column. In general, however, there is little evidence for the presence of known FeOB in plumes associated with black smokers (Dick et al., 2013). This is in keeping with the finding that the majority of vent-associated iron mats either occur in systems not associated with black smokers, or are distal enough from the smokers themselves that entrainment of biogenic oxides in plumes is limited.

At hydrothermal vents where microbial iron mats are actively accreting, presumably there is continual shedding of biogenic oxides from mat into the surrounding seawater. Detailed ultrastructural analysis of the iron oxides produced by stalk-forming and sheath-forming FeOB reveal the oxides are composed of nanometer scale fibrils that wind together to produce larger, micron scale structures (Chan et al., 2009, 2010). These are often referred to as hydrous ferric oxides (Fortin and Langley, 2005; Suzuki et al., 2011). They have large reactive surface areas, but are also delicate, with the potential to breakdown to nanoparticulate oxides of a size consistent with the dFe in the ocean (Ferris et al., 2015). The extent of this process, or how much these biogenic oxides could contribute to dFe budgets is unknown; nor is it known if biogenic oxides are a good iron source for phytoplankton and other microbes.

Our understanding of the flux and dynamics of biogenic iron oxide production is also rudimentary, as are estimates of actual in situ activities of FeOB. Glazer and Rouxel (2009) used an in situ microsensor to conduct a high resolution depth profile of an iron mat at Loihi Seamount that revealed steep gradients of $\mathrm{Fe}$ (II) within a $2-3 \mathrm{~cm}$ thick microbial iron mat, and a net transport of $\mathrm{Fe}$ (II) out of the mat. They found that as $\mathrm{O}_{2}$ concentration of the overlaying seawater decreased, there is a greater flux of $\mathrm{Fe}$ (II) out of the mat. Based on modeling of $\mathrm{O}_{2}$ and $\mathrm{Fe}$ (II) fluxes in
Loihi iron mats it was estimated that a range of $1 \times 10^{7}-4 \times 10^{8}$ cells $\mathrm{cm}^{-2} \mathrm{yr}^{-1}$ could be supported on $\mathrm{Fe}$ (II)-fueled growth (Glazer and Rouxel, 2009). As yet, there are no experimentally based estimates of microbial iron oxidation rates from deepsea hydrothermal iron mats. Cell-specific iron oxide production rates will be important for understanding the overall potential for biogenic iron oxides to contribute to the pool of dFe in the deep ocean.

\section{THE IMPORTANCE OF DIFFUSE HYDROTHERMAL FLOWS AS A SOURCE OF BIOGENIC IRON}

Most a priori assumptions are that black smoker systems are the major source of iron to the ocean; however, recent assessments indicate diffuse hydrothermal flow systems may contribute as much or more dFe to the ocean. Compared to black smokers, it is difficult to constrain the total flux of hydrothermal fluids from diffuse systems, since they can vary widely in flow rates and temperature. Studies from the Juan de Fuca Ridge hydrothermal vent system estimated $\geq 90 \%$ of the mass flow was sourced from diffuse flows (Rona and Trivett, 1992; Baker et al., 1993; Schultz and Elderfield, 1997). Remarkably, a recent modeling analysis by German et al. (2015) suggested that up to $90 \%$ of the $\mathrm{dFe}$ that is supplied by hydrothermal venting to the distal ocean originates from these diffuse sources. A recent analysis of $\mathrm{dFe}$ concentrations from a transect of the southern Pacific ocean stretching 4,000 km west from the East Pacific Rise ridge axis, revealed significantly higher $\mathrm{dFe}$ concentrations in deep ocean water than would have been predicted based on standard models of iron deposition from hydrothermal systems (Resing et al., 2015). The authors attribute much of this dFe to diffuse flow sources. These results confirm the probability that $\mathrm{dFe}$, often stabilized by ill-defined organic ligands, can be transported over basin-scale distances in the ocean. Furthermore, these authors estimate the global supply of dFe from ridge axes may be three to $4 \mathrm{Gmol}$ per year, nearly fourfold higher than previous estimates.

Another challenging facet of diffuse venting systems that harbor microbial iron mats is that they can be challenging to find, especially if they are not associated with high temperature vent fields. These systems can exhibit small temperature anomalies and produce minimal buoyant plumes that are often used to detect hydrothermal vents. A particularly striking case was the fortuitous discovery of meter thick microbial mats of iron and manganese-oxidizing bacteria associated with the base of Loihi Seamount at a depth of 5,000 m (Edwards et al., 2011). This ecosystem covered $100 \mathrm{~s}$ of $\mathrm{m}^{2}$, and had localized temperature anomalies ranging from a few tenths to a few degrees $\mathrm{C}$ above the background seawater. The extent of diffuse and ultra-diffuse sources that are geographically isolated from high temperature systems (e.g., $>100^{\circ} \mathrm{C}$ ) along tectonically active ridge crests or around seamounts is an unknown. Is it possible there are numerous, low temperature diffuse, iron-rich 'springs' dotted along the ocean ridges and around active seamounts, and, if so, how important a role might they play in the biogeochemical cycle of iron at the seafloor? When coupled with the capacity for FeOB 
to produce hydrous, nanoparticulate iron oxides, this opens the possibility for biogenic oxides to make a significant contribution to dFe in the global ocean.

\section{SEDIMENTARY IRON SOURCES THAT FUEL THE MICROBIAL IRON CYCLE}

Sedimentary sources of iron are an important source of $\mathrm{dFe}$ to the ocean, especially along continental margins. Recent modeling efforts suggest that the amount of dFe $(\sim 109 \mathrm{Gmol}$ $\mathrm{yr}^{-1}$ ) contributed by continental shelves to the global ocean is several times greater than previous estimates (Dale et al., 2015). Some marine sediments contain substantial amounts of reactive iron oxides that may support levels of iron reduction that rival or exceed rates of sulfate reduction (Thamdrup, 2000). Although sulfate is the major anion in anoxic marine environments that microorganisms use as an electron acceptor for anaerobic respiration, Fe-reduction is the thermodynamically favored process and so can outcompete sulfate reduction if reactive iron oxides are sufficiently available (Lovley and Phillips, 1987). A confounding factor for this biological process is that the hydrogen sulfide that results from sulfate reduction can chemically react with poorly crystalline iron oxides resulting in the formation of iron sulfides (Thamdrup and Canfield, 1996). Furthermore the reactivity of different oxidation states of iron with organic matter as well as soluble $\mathrm{Fe}(\mathrm{III})$ can further complicate biotic versus abiotic iron chemistry (Beckler et al., 2015). Nonetheless, it is assumed that microbes play an important role in iron reduction, although few marine ironreducing bacteria have actually been isolated. As a result, our knowledge about their physiology and ecology, compared to terrestrial strains, is lacking. For example, little is known about the metabolic flexibility of marine iron reducers. Presumably a significant percentage of them can reduce sulfate as well as iron oxides, but are there appreciable numbers of obligate marine iron reducers in marine sediments?

A number of measurements have been made for the benthic flux of iron from continental margin sediments from the west coast of the United States, with other measurements along the Peru Margin and South Africa, as well as sediments in the embayments of Arctic glaciers (Severmann et al., 2010; Noffke et al., 2012; Homoky et al., 2013; Wehrmann et al., 2014). To cite specific examples, measured porewater concentrations of $\mathrm{Fe}(\mathrm{II})$ ranging from around 5 to $180 \mu \mathrm{M}$ have led to modeled iron effluxes that can range from $\sim 2.5 \mu \mathrm{mol} \mathrm{m}^{-2} \mathrm{day}^{-1}$ up to $100 \mu \mathrm{mol} \mathrm{m}^{-2}$ day $^{-1}$ (Homoky et al., 2012). Even higher fluxes of iron have been reported from sediments associated with an oxygen minimum zone off the coast of Peru, where porewater concentrations of $\mathrm{Fe}(\mathrm{II})$ up to $90 \mu \mathrm{M}$ were measured (Dang et al., 2011; Noffke et al., 2012). An important point is that these higher porewater $\mathrm{Fe}(\mathrm{II})$ values are well within the known minimal concentration (1-10 $\mu \mathrm{M})$ of Fe(II) that would support the growth of $\mathrm{FeOB}$, so long as there is a sufficient $\mathrm{Fe}(\mathrm{II})$ flux. The highest porewater $\mathrm{Fe}(\mathrm{II})$ concentrations tend to be within a couple centimeters of the sediment surface, and implies relatively steep gradients of $\mathrm{Fe}(\mathrm{II})$ could provide an energy source for $\mathrm{FeOB}$ growing in the micro-oxic zone near the sediment surface. The slope or trajectory of these gradients in the sediments will be governed by the $\mathrm{O}_{2}$ demand related to the availability of organic matter, as well as the $\mathrm{O}_{2}$ concentration of the overlying water.

The most striking evidence for iron oxidation is observation of rust-colored oxides, for example the thick floculant mats that form around hydrothermal vents. If the relative rates of iron reduction are high, either through microbial reduction or chemical reduction with sulfide, then iron oxides will be reduced quickly and there will be minimal accumulation of iron oxides. Furthermore, currents and wave action will tend to disperse hydrous ferric oxides that accumulate on surface sediments. These processes could lead to a cryptic iron cycle. A key question then revolves around the extent to which populations of $\mathrm{FeOB}$ are present, and active. Even if the numbers of $\mathrm{FeOB}$ in these sediments are relatively low, e.g., $10^{5}-10^{6}$ cells $\mathrm{cc}^{-1}$ compared to the total cell populations of $10^{8}-10^{9}$ cells $\mathrm{cc}^{-1}$, they could be oxidizing a significant amount of $\mathrm{Fe}(\mathrm{II})$. Ultimately, their activity will determine the balance of the iron cycle between reduction and oxidation, and constrain the release of either Fe(II) or hydrous ferric oxides from the sediments.

While the role of $\mathrm{FeOB}$ in these processes is still largely unknown, there is a growing body of evidence indicating that they are present and active. Studies of bio-corrosion of mild steel in both Maine and China have shown that $\mathrm{FeOB}$ can rapidly colonize steel surfaces (Dang et al., 2011; Mcbeth et al., 2011). These results indicate there must be a local reservoir of $\mathrm{FeOB}$, most likely in shallow marine sediments, or nearby brackish environments (Mcbeth et al., 2013), or through aquifer-based intertidal mixing zones. In support of this latter source, a recent study of an intertidal zone in Delaware found significant levels of biological iron oxidation, and evidence for marine $\mathrm{FeOB}$ along a beach front where a freshwater aquifer rich in $\mathrm{Fe}(\mathrm{II})$ was upwelling into the ocean (McAllister et al., 2015). A recent modeling study of submarine groundwater discharge along continental margins estimated the flux of these groundwaters could be three to four times greater than riverine inputs into the ocean (Kwon et al., 2014). It is well known in the water industry that aquifers often contain appreciate levels of iron, and $\mathrm{FeOB}$ are common (Emerson and de Vet, 2015). Thus it is possible these anoxic or hypoxic waters could be a significant source of $\mathrm{Fe}(\mathrm{II})$ as well as $\mathrm{FeOB}$ and iron-reducing bacteria, that could feed an active microbial iron cycle in near shore sediments.

A survey of the Levantine margin off the coast of Israel found visual evidence for iron oxide deposits on the seafloor at depths of 300-800 m (Rubin-Blum et al., 2014). Molecular analysis revealed the presence of putative $\mathrm{FeOB}$ belonging to the Zetaproteobacteria as dominant members of these communities. The iron-oxidizing communities were associated with animal burrows, where presumably bioturbation and ventilation of the sediments led to a situation allowing for transport of $\mathrm{O}_{2}$ into anoxic sediments enriched in $\mathrm{Fe}(\mathrm{II})$ providing an ideal habitat with counter-gradients free $\mathrm{Fe}(\mathrm{II})$ and $\mathrm{O}_{2}$. Worm burrows in shallow sediments can also be a source of iron oxide precipitates where $\mathrm{FeOB}$ are present (McAllister et al., 2015). These initial studies suggest biological Fe-oxidation in marine sediments is far more common than previously realized. If this 
phenomenon is widespread, then FeOB may play a significant role in transforming iron, and controlling both the kinetics and the quality of iron transported into the water column.

\section{THE MICROBIAL IRON CYCLE IN A CHANGING OCEAN}

Continuing build-up of carbon dioxide in the atmosphere is a primary driver of climate change, global warming, ocean acidification, and sea-level rise. The impact of these affects on hydrothermally derived iron to the global ocean will come about as a result of changes in oceanic circulation patterns that are difficult to predict, but could have major impacts, either positive or negative, on delivery of iron to the ocean's anemic regions. A better understanding of biogenically produced iron associated with hydrothermal vents will aid our understanding of how this could ultimately affect iron distribution patterns. In terms of near shore benthic habitats, climate change will have more direct impacts, through increased hypoxia and acidification. In general, anoxic and hypoxic conditions will favor iron reduction and the release of $\mathrm{Fe}$ (II) into the water column. Hypoxia will favor microbial Fe-oxidation. Likewise, the kinetics of Fe-oxidation are most sensitive to $\mathrm{pH}$, thus decreasing $\mathrm{pH}$ will enhance the stability of $\mathrm{Fe}(\mathrm{II})$ making it more available for microbial Fe-oxidation. Thus one might predict a strengthening of the iron cycle, which would have important feedbacks to the supply of dFe to open, sunlit ocean, where primary productivity would be enhanced. On the other hand, hypoxic bottom waters will lead to die-offs of sedimentary in-fauna leading to decreased

\section{REFERENCES}

Anderson, J. S., Rittle, J., and Peters, J. C. (2013). Catalytic conversion of nitrogen to ammonia by an iron model complex. Nature 501, 84-87. doi: 10.1038 /nature 12435

Baken, S., Salaets, P., Desmet, N., Seuntjens, P., Vanlierde, E., and Smolders, E. (2015). Oxidation of iron causes removal of phosphorus and arsenic from streamwater in groundwater-fed lowland catchments. Environ. Sci. Technol. 49, 2886-2894. doi: 10.1021/es505834y

Baker, E. T., Massoth, G. J., Walker, S. L., and Embley, R. W. (1993). A method for quantitatively estimating diffuse and discrete hydrothermal discharge. Earth Planet. Sci. Lett. 118, 235-249. doi: 10.1016/0012-821X(93)90170-E

Beckler, J. S., Jone, M. E., and Tallefert, M. (2015). The origin, composition, and reactivity of dissolved iron(III) complexes in coastal organicand iron-rich sediments. Geochim. Cosmochim. Acta 152, 72-88. doi: 10.1016/j.gca.2014.12.017

Bennett, S. A., Hansman, R. L., Sessions, A. L., Nakamura, K.-I., and Edwards, K. J. (2011). Tracing iron-fueled microbial carbon production within the hydrothermal plume at the Loihi seamount. Geochim. Cosmochim. Acta 75, 5526-5539. doi: 10.1016/j.gca.2011.06.039

Bennett, S. A., Toner, B. M., Barco, R., and Edwards, K. J. (2014). Carbon adsorption onto $\mathrm{Fe}$ oxyhydroxide stalks produced by a lithotrophic ironoxidizing bacteria. Geobiology 12, 146-156. doi: 10.1111/gbi.12074

Chan, C. S., Fakra, S. C., Edwards, D. C., Emerson, D., and Banfield, J. F. (2009). Iron oxyhydroxide mineralization on microbial extracellular polysaccharides. Geochim. Cosmochim. Acta 73, 3807-3818. doi: 10.1016/j.gca.2009. 02.036

Chan, C. S., Fakra, S. C., Emerson, D., Fleming, E. J., and Edwards, K. J. (2010). Lithotrophic iron-oxidizing bacteria produce organic stalks to control mineral bioturbation and bioirrigation of sediments. Could this more than counter-balance the factors of hypoxia and lower $\mathrm{pH}$ ? Finally, the iron and phosphorus cycles are linked due to the capacity for iron-oxyhydroxides to strongly adsorb phosphate. Although, it is known that iron minerals associated with hydrothermal plumes play a role in scavenging phosphorus (Dick et al., 2013), specific interactions between biogenic iron oxides and phosphorous have not been studied in marine systems. Recent work in terrestrial environments has shown the presence of biogenic iron oxides can significantly influence phosphorus dynamics (Baken et al., 2015) thus it is reasonable to expect similar interactions could be important in the ocean. These and many other questions about the roles of microbes in the marine iron cycle are worthy of study, and will undoubtedly reveal even more ironies about iron.

\section{FUNDING}

Support was provided by the National Science Foundation grants OCE-1155754 and OCE-1459600, and funds from the Center for Dark Energy Biosphere Investigations (C-DEBI). This is C-DEBI contribution no. 297.

\section{ACKNOWLEDGMENTS}

I would like to thank Chris German, Ben Twining, and George Luther III for comments on an earlier version of this manuscript. The funder had no role in any of the ideas expressed in, or decision to publish, the manuscript.

growth: implications for biosignature formation. ISME J. 5, 717-727. doi: 10.1038/ismej.2010.173

Dale, A. W., Nickelsen, L., Scholz, F., Hensen, C., Oschlies, A., and Wallman, K. (2015). A revised global estimate of dissolved iron fluxes from marine sediments. Glob. Biogeochem. Cycles 29, 691-707. doi: 10.1002/2014GB00 5017

Dang, H., Chen, R., Wang, L., Shao, S., Dai, L., Ye, Y., et al. (2011). Molecular characterization of putative biocorroding microbiota with a novel niche detection of Epsilon- and Zetaproteobacteria in Pacific Ocean coastal seawaters. Environ. Microbiol. 13, 3059-3074. doi: 10.1111/j.1462-2920.2011.02583.x

Dick, G. J., Anantharaman, K., Baker, B. J., Li, M., Reed, D. C., and Sheik, C. S. (2013). The microbiology of deep-sea hydrothermal vent plumes: ecological and biogeographic linkages to seafloor and water column habitats. Front. Microbiol. 4:124. doi: 10.3389/fmicb.2013.00124

Edwards, K. J., Glazer, B. T., Rouxel, O. J., Bach, W., Emerson, D., Davis, R. E., et al. (2011). Ultra-diffuse hydrothermal venting supports Fe-oxidizing bacteria and massive umber deposition at 5000m off Hawaii. ISME J. 5, 1748-1758. doi: 10.1038/ismej.2011.48

Emerson, D., and de Vet, W. (2015). The role of FeOB in engineered water ecosystems: a review. J. Am. Water Works Assoc. 107, E47-E57. doi: 10.5924/jawwa.2015.107.0004

Emerson, D., Fleming, E. J., and Mcbeth, J. M. (2010). Iron-oxidizing bacteria: an environmental and genomic perspective. Annu. Rev. Microbiol. 64, 561-583. doi: 10.1146/annurev.micro.112408.134208

Emerson, D., and Moyer, C. L. (2010). Microbiology of seamounts. Oceanography 23, 1-16. doi: 10.5670/oceanog.2010.67

Ferris, F. G., James, R. E., and Pedersen, K. (2015). Fragmentation of bacteriogenic iron oxides in response to hydrodynamic shear stress. Geomicrobiol. J. 32, 564-569. doi: 10.1080/01490451.2014.897775 
Fitzsimmons, J. N., Boyle, E. A., and Jenkins, W. J. (2014). Distal transport of dissolved hydrothermal iron in the deep South Pacific Ocean. Proc. Natl. Acad. Sci. U.S.A. 111, 16654-16661. doi: 10.1073/pnas.1418778111

Fortin, D., and Langley, S. (2005). Formation and occurrence of biogenic iron-rich minerals. Earth Sci. Rev. 72, 1-19. doi: 10.1111/j.1472-4669.2007. 00131.x

Gartman, A., Findlay, A. J., and Luther, G. W. III. (2014). Chemical Geology. Chem Geol. 366, 32-41. doi: 10.1016/j.chemgeo.2013.12.013

German, C. R., Legendre, L. L., Sander, S. G., Niquil, N., Luther, G. W. III, Bharati, L., et al. (2015). Earth and planetary science letters. Earth Planet. Sci. Lett. 419, 143-153. doi: 10.1016/j.epsl.2015.03.012

Glazer, B. T., and Rouxel, O. J. (2009). Redox speciation and distribution within diverse iron-dominated microbial habitats at loihi seamount. Geomicrobiol. J. 26, 606-622. doi: 10.1080/01490450903263392

Homoky, W. B., John, S. G., Conway, T. M., and Mills, R. A. (2013). Distinct iron isotopic signatures and supply from marine sediment dissolution. Nat. Commun. 4, 1-10. doi: 10.1038/ncomms3143

Homoky, W. B., Severmann, S., McManus, J., Berelson, W. M., Riedel, T. E., Statham, P. J., et al. (2012). Dissolved oxygen and suspended particles regulate the benthic flux of iron from continental margins. Mar. Chem. 134-135, 59-70. doi: 10.1016/j.marchem.2012.03.003

Kwon, E. Y., Kim, G., Primeau, F., Moore, W. S., Cho, H.-M., DeVries, T., et al. (2014). Global estimate of submarine groundwater discharge based on an observationally constrained radium isotope model. Geophys. Res. Lett. 41, 8438-8444. doi: 10.1002/2014GL061574

Lovley, D. R., and Phillips, E. J. P. (1987). Competitive mechanisms for inhibition of sulfate reduction and methane production in the zone of ferric iron reduction in sediments. Appl. Environ. Microbiol. 53, 2636-2641.

Martin, J. H., Gordon, M., and Fitzwater, S. E. (1990). Iron in Antarctic waters. Nature 345, 156-158. doi: 10.1038/345156a0

McAllister, S. M., Barnett, J. M., Heiss, J. W., Findlay, A. J., MacDonald, D. J., Dow, C. L., et al. (2015). Dynamic hydrologic and biogeochemical processes drive microbially enhanced iron and sulfur cycling within the intertidal mixing zone of a beach aquifer. Limnol. Oceanogr. 60, 329-345. doi: 10.1111/lno. 10029

Mcbeth, J. M., Fleming, E. J., and Emerson, D. (2013). The transition from freshwater to marine iron-oxidizing bacterial lineages along a salinity gradient on the Sheepscot River, Maine, USA. Environ. Microbiol. Rep. 5, 453-463. doi: 10.1111/1758-2229.12033

Mcbeth, J. M., Little, B. J., Ray, R. I., Farrar, K. M., and Emerson, D. (2011). Neutrophilic iron-oxidizing "zetaproteobacteria" and mild steel corrosion in nearshore marine environments. Appl. Environ. Microbiol. 77, 1405-1412. doi: 10.1128/AEM.02095-10

Moore, J. K., and Braucher, O. (2008). Sedimentary and mineral dust sources of dissolved iron to the world ocean. Biogeosciences 5, 631-656. doi: 10.5194/bg-5631-2008-supplement

Noffke, A., Hensen, C., Sommer, S., Scholz, F., Bohlen, L., Mosch, T., et al. (2012). Benthic iron and phosphorus fluxes across the Peruvian oxygen minimum zone. Limnol. Oceanogr. 57, 851-867. doi: 10.4319/lo.2012.57.3.0851

Raiswell, R., and Canfield, D. E. (2011). The iron biogeochemical cycle past and present. Geochem. Perspect. 1, 1-2. doi: 10.7185/geochempersp.1.1

Raven, J. A., Evans, M. C. W., and Korb, R. E. (1999). The role of trace metals in photosynthetic electron transport in O2- evolving organisms. Photosyn. Res. 60, 111-149. doi: 10.1023/A:1006282714942

Resing, J. A., Sedwick, P. N., German, C. R., Jenkins, W. J., Moffett, J. W., Sohst, B. M., et al. (2015). Basin-scale transport of hydrothermal dissolved metals across the South Pacific Ocean. Nature 523, 200-203. doi: 10.1038/nature14577

Rona, P. A., and Trivett, D. A. (1992). Discrete and diffuse heat transfer at ASHES vent field Axial Volcano, Juan de Fuca Ridge. Earth Planet. Sci. Lett. 109, 57-71. doi: 10.1016/0012-821X(92)90074-6

Rubin-Blum, M., Antler, G., Tsadok, R., Shemesh, E., Austin, J. A., Coleman, D. F., et al. (2014). First evidence for the presence of iron oxidizing Zetaproteobacteria at the Levantine continental margins. PLOS ONE 9:e91456. doi: 10.1371/journal.pone.0091456.s004
Schultz, A., and Elderfield, H. (1997). Controls on the physics and chemistry of seafloor hydrothermal circulation?philosophical transactions of the royal society a: mathematical. Phys. Eng. Sci. 355, 387-425. doi: 10.1098/rsta.1997.0014

Scott, J. J., Breier, J. A., Luther, G. W., and Emerson, D. (2015). Microbial iron mats at the mid-atlantic ridge and evidence that zetaproteobacteria may be restricted to iron-oxidizing marine systems. PLoS ONE 10:e0119284. doi: 10.1371/journal.pone.0119284.t002

Severmann, S., McManus, J., Berelson, W. M., and Hammond, D. E. (2010). The continental shelf benthic iron flux and its isotope composition. Geochim. Cosmochim. Acta 74, 3984-4004. doi: 10.1016/j.gca.2010.04.022

Suzuki, T., Hashimoto, H., Matsumoto, N., Furutani, M., Kunoh, H., and Takada, J. (2011). Nanometer-scale visualization and structural analysis of the inorganic/organic hybrid structure of Gallionella ferruginea twisted stalks. Appl. Environ. Microbiol. 77, 2877-2881. doi: 10.1128/AEM.02867-10

Sylvan, J. B., Pyenson, B. C., Rouxel, O., German, C. R., and Edwards, K. J. (2012). Time-series analysis of two hydrothermal plumes at $9^{\circ} 50^{\prime} \mathrm{N}$ East Pacific Rise reveals distinct, heterogeneous bacterial populations. Geobiology 10, 178-192. doi: 10.1111/j.1472-4669.2011.00315.x

Tagliabue, A. (2014). More to hydrothermal iron input than meets the eye: Fig. 1. Proc. Natl. Acad. Sci. U.S.A. 111, 16641-16642. doi: 10.1073/pnas.1419829111

Tagliabue, A., Bopp, L., Dutay, J.-C., Bowie, A. R., Chever, F., Jean-Baptiste, P., et al. (2010). Hydrothermal contribution to the oceanic dissolved iron inventory. Nat. Geosci. 3, 252-256. doi: 10.1038/ngeo818

Tagliabue, A., Sallée, J.-B., Bowie, A. R., Lévy, M., Swart, S., and Boyd, P. W. (2014). Surface-water iron supplies in the Southern Ocean sustained by deep winter mixing. Nat. Geosci. 7, 314-320. doi: 10.1038/ngeo2101

Thamdrup, B. (2000). Bacterial manganese and iron reduction in aqautic sediments. Adv. Microbial. Ecol. 16, 41-84. doi: 10.1111/j.15746941.2010.01036.x

Thamdrup, B., and Canfield, D. E. (1996). Pathways of carbon oxidation in continental margin sediments off central Chile. Limnol. Oceanogr. 41, 16291650. doi: 10.4319/lo.1996.41.8.1629

Toner, B. M. (2012). Mineralogy of iron microbial mats from Loihi Seamount. Front. Microbiol. 3:118. doi: 10.3389/fmicb.2012.00118/abstract

Toner, B. M., Fakra, S. C., Manganini, S. J., Santelli, C. M., Marcus, M. A., Moffett, J. W., et al. (2009). Preservation of iron(II) by carbon-rich matrices in a hydrothermal plume. Nat. Geosci. 2, 197-201. doi: 10.1038/ngeo433

Toner, B. M., Santelli, C. M., Marcus, M. A., Wirth, R., Chan, C. S., Mccollom, T., et al. (2008). Biogenic iron oxyhydroxide formation at mid-ocean ridge hydrothermal vents: Juan de Fuca Ridge. Geochim. Cosmochim. Acta 73, 388403. doi: 10.1016/j.gca.2008.09.035

Wehrmann, L. M., Formolo, M. J., Owens, J. D., Raiswell, R., Ferdelman, T. G., Riedinger, N., et al. (2014). Iron and manganese speciation and cycling in glacially influenced high-latitude fjord sediments (West Spitsbergen, Svalbard): evidence for a benthic recycling-transport mechanism. Geochim. Cosmochim. Acta 141, 628-655. doi: 10.1016/j.gca.2014.06.007

Wu, J., Wells, M. L., and Rember, R. (2011). Dissolved iron anomaly in the deep tropical-subtropical Pacific: evidence for long-range transport of hydrothermal iron. Geochim. Cosmochim. Acta 75, 460-468. doi: 10.1016/j.gca.2010.10.024

Yücel, M., Gartman, A., Chan, C. S., and Luther, G. W. (2011). Hydrothermal vents as a kinetically stable source of iron-sulphide-bearing nanoparticles to the ocean. Nat. Geosci. 4, 1-5. doi: 10.1038/ngeo1148

Conflict of Interest Statement: The author declares that the research was conducted in the absence of any commercial or financial relationships that could be construed as a potential conflict of interest.

Copyright (C) 2016 Emerson. This is an open-access article distributed under the terms of the Creative Commons Attribution License (CC BY). The use, distribution or reproduction in other forums is permitted, provided the original author(s) or licensor are credited and that the original publication in this journal is cited, in accordance with accepted academic practice. No use, distribution or reproduction is permitted which does not comply with these terms. 